\title{
Effect of high hydrostatic pressure on the antioxidant capacity and peptic hydrolysis of whey proteins
}

\author{
Ana Paula Miguel Landim ${ }^{1}$ Davy William Hidalgo Chávez ${ }^{1}$ Jeane Santos da Rosa ${ }^{2}$ D \\ Caroline Mellinger-Silva ${ }^{2 *}$ Amauri Rosenthal ${ }^{2}$ iD
}

${ }^{1}$ Departamento de Tecnologia de Alimentos, Universidade Federal Rural do Rio de Janeiro (UFRRJ), Seropédica, RJ, Brasil

${ }^{2}$ Embrapa Agroindústria de Alimentos, 23020-470, Rio de Janeiro, RJ, Brasil. E-mail: caroline.mellinger@embrapa.br. "Corresponding author.

ABSTRACT: The effect of high hydrostatic pressure (HHP) application on whey protein concentrate was evaluated both before (pre-treatment - PT) and during (hydrolysis assisted - HA) hydrolysis processes. A factorial design 22 with 3 central points was used with pressure (100, 250, $400 \mathrm{MPa})$ and time (5, 20 and 35 minutes) as independent variables. The hydrolysis was evaluated and monitored by soluble protein, aromatic amino acid contents and RP-HPLC. ABTS and ORAC tests were used to evaluate the in vitro antioxidant capacity. The reduction of soluble protein content was approximately $20 \%$ for conventional hydrolysis and for all PT treatments up to 4 h of reaction, while HHP assisted hydrolysis at $100 \mathrm{MPa}$ showed a 35\% protein reduction after 35 minutes of reaction. In addition, pressurization favored peptic hydrolysis of $\beta$-lactoglobulin by up to $98 \%$ and also improved the in vitro antioxidant capacity of the hydrolysates, which increased from 34.25 to 60.89 umoles TE g-1 of protein in the best treatment. The results suggest that the use of HHP assisted hydrolysis favored the peptic hydrolysis, with a reduction in hydrolysis time and increased antioxidant activity.

Key words: Enzymatic hydrolysis, Pepsin, High hydrostatic pressure, Antioxidant capacity.

Efeito da alta pressão hidrostática na hidrólise péptica das proteínas do soro de leite e na capacidade antioxidante

RESUMO: Neste estudo, o efeito da aplicação de alta pressão hidrostática (HHP) sobre o concentrado proteico de soro de leite foi avaliado antes (pré-tratamento - PT) e durante os processos de hidrólise (assistida por hidrólise - HA). Utilizou-se o delineamento fatorial 22 com três pontos centrais, onde as variáveis independentes foram pressão (100, 250, $400 \mathrm{MPa}$ ) e tempo (5, 20 e 35 minutos). A hidrólise foi avaliada pelo conteúdo de proteinas solúveis e aminoácidos aromáticos, além do perfil peptídico por RP-HPLC. As análises de ABTS e ORAC foram utilizadas para avaliar a capacidade antioxidante in vitro. A redução do teor de proteína solúvel foi de aproximadamente $20 \%$ para a hidrólise convencional e para todos os pontos de PT até 4 h de reação, enquanto a hidrólise assistida por HHP a 100 MPa mostrou uma redução de 35\% de proteína em 35 minutos de reação. Além disso, a pressurização favoreceu a hidrólise péptica da $\beta$-lactoglobulina em até $98 \%$ e também melhorou a capacidade antioxidante in vitro dos hidrolisados, que aumentaram de 34,25 para 60,89 $\mu$ moles de TE g-1 de proteina no melhor tratamento. Os resultados sugerem que o uso da hidrólise assistida por HHP favoreceu a hidrólise péptica, com redução no tempo de hidrólise e aumento da atividade antioxidante.

Palavras-chave: Hidrólise enzimática, Pepsina, Alta pressão hidrostática, Capacidade antioxidante.

\section{INTRODUCTION}

Whey and its derivatives are the main coproducts of the dairy industry and it contains about $55 \%$ of milk nutrients, and makes up approximately $85-95 \%$ of the total milk volume, while whey proteins account for approximately $20 \%$ of total milk protein. They are mainly composed of $\beta$ - lactoglobulin (55$60 \%$ ) and a-lactalbumin (15-20\%) and, to a lesser extent, immunoglobulins (Igs), bovine serum albumin (BSA), lactoferrin (LF), lactoperoxidase (LP), and peptone protease (PP) (YADAV et al., 2015).

Protein hydrolysates obtained from whey are widely used as food ingredients due to their high nutritional value. Moreover, they have improved bioactive properties, such as antioxidant, antihypertensive, antitumor, and antibacterial actions, among others (BRANDELLI etl al., 2015; MARSHALL, 2004) and the study of these properties are important for adding value to the product and directly influencing consumers' choice (CHEISON \& KULOZIK, 2017).

However, it is difficult to achieve a high degree of hydrolysis of whey proteins through the use of a single enzyme, especially in proteins having a globular structure and hydrophobic core, such as $\beta$-lactoglobulin. The specific cleavage points in the 
peptide chain are not accessible to the enzyme, making the hydrolysis process less efficient (ABADÍAGARCÍA et al., 2016; TAVARES et al., 2012). The modification of the protein conformation, especially the unfolding of the protein, is an interesting strategy to improve the efficiency of the enzymatic reactions. This strategy leads to a greater exposure of cleavage points to enzymatic attack, causing the reaction to occur in a shorter time and more efficiently (AMBROSI et al., 2016).

To this effect, high hydrostatic pressure (HHP), one of the most sustainable and ecological technologies for food technology, has been specially studied with the purpose of inducing structural and conformational changes in proteins. It has a considerable effect on the mobilization of weak bonds, such as hydrogen bonds and electrostatic interactions, promoting unfolding of tertiary and secondary structures and leading to protein denaturation (MARCINIAK et al., 2018; MUNIR et al., 2019). In addition, proteins that have globular conformation, such as whey proteins, are more likely to be altered by the use of HHP. Among whey proteins, $\beta$-lactoglobulin presents higher barosensitivity when compared to $\beta$-lactoalbumin, favouring the use of HHP to unfold it (AMBROSI et al., 2016; HUPPERTZ et al., 2006; MUNIR et al., 2019). Some studies confirm the effect of high hydrostatic pressure on the enzymatic hydrolysis of whey (AMBROSI et al., 2016; GARCIA-MORA et al., 2015; LOZANOOJALVO et al., 2017; PEÑAS et al., 2006) and in the increase of bioactive activities, such as antioxidant capacity (ISKANDAR et al., 2015; PICCOLOMINI et al., 2012).

However, in these previous studies, a multi-factorial experimental design was not used to optimize the hydrolysis process using HHP, evaluating pressure and time parameters together, as their interaction may influence on protein hydrolysis. Thus, a predictive model of the effects of these hydrolysis parameters and optimization of the conditions can be investigated, and the response surface methodology (RSM) has been described as a useful empirical tool to optimize the process of conventional hydrolysis of whey (PESSATO et al., 2016) and caseins (NONGONIERMA et al., 2016). Also, since HHP can be used in the form of a pretreatment or assisting the hydrolysis process, it is important to understand the reactions and responses of the treatments to the variation of the evaluated parameters.

Thus, in this study, the applicability of HHP treatment was evaluated, and the effect of this treatment was evaluated for the enzymatic hydrolysis and antioxidant properties of whey protein concentrate (WPC) solutions, using the enzyme pepsin as a biocatalyst and the RSM to select the ideal conditions in which the HHP should be used.

\section{MATERIALS AND METHODS}

\section{Material}

A WPC powder containing $88 \%$ protein, which was kindly donated by Alibra Ingredientes Ltda, was used as the substrate. Commercial grade swine pepsin TS was supplied by the Coal and Coagulants Factory Bela Vista Produtos Enzimáticos Ind. E Com. Ltda.

\section{Preparation of protein hydrolysates Preparation of whey}

For all experiments, the WPC 88 was solubilized in water at $2.5 \%(\mathrm{w} / \mathrm{v})$ concentration. The enzymatic reactions were performed with $1.96 \%$ pepsin, and the enzyme catalytic activity was $0.28 \mu \mathrm{U}$ $\mathrm{mL}^{-1}$. The $\mathrm{pH}$ and temperature of the solution were adjusted to the optimal range of the enzyme ( $\mathrm{pH} 2$ and $37^{\circ} \mathrm{C}$ ).

\section{Hydrolysis processes}

The hydrolysis were performed in three ways: conventional $(\mathrm{CH})$, using the HHP as pretreatment in the whey (PT) and assisted by HHP (AH), as follows.

Conventional hydrolysis $(\mathrm{CH})$ : In this process the whey protein resuspended $(2.5 \% \mathrm{w} / \mathrm{v})$ was placed in a thermostatic bath with temperature $\left(37^{\circ} \mathrm{C}\right)$ and constant stirring (16 rpm) for 15 minutes for acclimatization. The initial sample was collected (Control - C), and the enzyme was added for hydrolysis execution. The temperature, $\mathrm{pH}$, and stirring speed were monitored throughout the reaction, and samples were collected after 1 minute $\left(\mathrm{T}_{0}\right)$, 60 minutes $\left(\mathrm{T}_{60}\right), 120$ minutes $\left(\mathrm{T}_{120}\right), 180$ minutes $\left(\mathrm{T}_{180}\right)$, a 240 minutes $\left(\mathrm{T}_{240}\right)$ of hydrolysis. After, the enzymatic action was immediately stopped by placing the samples in a water bath at $80{ }^{\circ} \mathrm{C}$ for 15 minutes, followed by immediate cooling in an ice bath. All samples were freeze-dried and stored under freezing condition $\left(-18^{\circ} \mathrm{C}\right)$ for further analysis.

\section{HHP pretreatment (PT)}

The resuspended whey protein has been subjected to the process of high hydrostatic pressure (HHP), using different pressure and time levels for each treatment. The samples were packed in high strength polyethylene bags, vacuum sealed, and then, pressurized using the high hydrostatic pressure 
equipment (Stanted Fluid Power and model SFL-850-9-W). Afterwards, the pre-treated whey was hydrolysed on the same conditions treatment described in the conventional hydrolysis.

$$
\text { HHP-assisted treatment }(A H) \text { : This }
$$

treatment the samples containing the whey and the enzyme were packed in high strength polyethylene bags, vacuum sealed, and immediately pressurized using the high hydrostatic pressure equipment (Stanted Fluid Power and model SF-L-850-9-W) in the different pressure and time levels for each treatment. Soon after, the enzyme was inactivated as previously described in the $\mathrm{CH}$.

\section{Experimental design}

In all the experiments in which high hydrostatic pressure (HHP) was used (pretreatment or assisted), and the treatment was carried out using a set of experiments followed the Boxe-Behnken Design (BOX \& BEHNKEN, 1960), formed by the combination of two-level factorial experiments with incomplete block designs. Error evaluation was obtained from the replicate of the central point.

The following second-order polynomial model (1) was used to analyze the experimental data: $y=b_{0}+b_{1} x_{1}+b_{2} x_{2}+b_{3} x_{1} x_{2}+b_{4} x_{1}^{2}+b_{5} x_{2}^{2}$

Where, $x_{\mathrm{i}}(\mathrm{i}=1-2)$ are the pressure and time variables; $y$ are the dependent variables (soluble proteins, aromatic amino acids, antioxidant capacity); and, $b_{\mathrm{i}(\mathrm{i}=1-5)}$ are the regression coefficients estimated by means of the multiple linear regression experimental data.
The different independent variables were described in Table 1.

\section{Chemical characterization Soluble protein content}

The evolution of hydrolysis during the process was verified by the soluble protein content, evaluated according to BRADFORD (1976), in which proteins and peptides greater than $3 \mathrm{kDa}$ are measured. Bovine serum albumin (BSA) was used as a protein standard.

\section{Aromatic amino acid content}

Samples were precipitated in volumes equal to $10 \%(\mathrm{w} / \mathrm{v})$ trichloracetic acid (TCA) over night at $4^{\circ} \mathrm{C}$ to remove large peptides. After, was centrifuged at $2146.56 \mathrm{~g}$ at $4{ }^{\circ} \mathrm{C}$ by 20 minutes. The supernatant was read in spectrophotometer at $280 \mathrm{~nm}$. Aromatic amino acid release was calculated from a tyrosine curve (GOODWIN \& MORTON, 1946).

\section{Chromatographic analysis of peptides and proteins}

Reversed phase high performance liquid chromatography (RP-HPLC) was used to analyze the peptide profiles generated by the hydrolysis and for the quantification of $\alpha$-lactoglobulin and $\beta$-lactalbumin proteins in the hydrolyzed samples. An analytical HPLC unit from Jasco was used. For the chromatographic analysis, lyophilized samples were resuspended in water $\left(2 \mathrm{mg} \mathrm{mL}^{-1}\right)$. The $\mathrm{pH}$ of 5.5 was adjusted to be similar to the mobile phase, and an injection volume of $20 \mu \mathrm{L}$ was used. The analyses were performed with a Hypersil BDS C18 column (100x4.6mm; $2.4 \mu$; Thermo, USA) with runs of 40

Table 1 - Experimental conditions of pressure and time in the hydrolysis treatments using the high hydrostatic pressure technology, according to the factorial design $2^{2}$ with 3 replicates of the central point.

\begin{tabular}{|c|c|c|c|c|c|}
\hline Assay & Pressure & Time & Assay & Pressure & Time \\
\hline AH1 & $-1(100)$ & $-1(5)$ & PT1 & $-1(100)$ & $-1(5)$ \\
\hline $\mathrm{AH} 2$ & $1(400)$ & $-1(5)$ & PT2 & $1(400)$ & $-1(5)$ \\
\hline AH3 & $-1(100)$ & $1(35)$ & PT3 & $-1(100)$ & $1(35)$ \\
\hline AH4 & $1(400)$ & $1(35)$ & PT4 & $1(400)$ & $1(35)$ \\
\hline AH5 (C) & $0(250)$ & $0(20)$ & PT5 (C) & $0(250)$ & $0(20)$ \\
\hline AH6 (C) & $0(250)$ & $0(20)$ & PT6 (C) & $0(250)$ & $0(20)$ \\
\hline AH7 (C) & $0(250)$ & $0(20)$ & PT7 (C) & $0(250)$ & $0(20)$ \\
\hline
\end{tabular}

${ }^{a}$ High hydrostatic pressure. Encoded values (actual values in parentheses). Unit of Real Values. Pressure in MPa and time in minutes. HHP - High hydrostatic pressure. 
minutes, using a flow of $1.0 \mathrm{~mL} /$ minutes, pressure of 126 bar, and temperature of $30{ }^{\circ} \mathrm{C}$. The mobile phases used were: (A): $0.1 \%$ trifluoroacetic acid (TFA) in ultrapure water (v/v); and (B): 0.1\% TFA in acetonitrile $(\mathrm{v} / \mathrm{v})$. Detection was performed by UV at $216 \mathrm{~nm}$.

\section{Antioxidant capacity ABTS Assay}

The antioxidant capacity was determined by the spectrophotometric method based on the discoloration of free radical $\mathrm{ABTS}^{+}\left(2,2^{\prime}\right.$-azinobis 3-ethylbenzothiazoline 6-sulfonate) according to RE et al., (1999). The results were expressed as TEAC (Trolox Equivalent Antioxidant Capacity) in $\mu$ moles TE $\mathrm{g}^{-1}$ protein.

\section{ORAC Assay}

The ORAC assay was performed according to the method described in ZULUETA et al., (2009). Fluorescein solutions, Trolox standard, and AAPH solution (2.2 Azobis, 2-methylpropionamide) dihydrochloride were prepared on the day of analysis. In a 96-well microplate, $100 \mu \mathrm{L}$ of the standard, 500fold diluted sample, and a blank (75 mM Phosphate buffer $\mathrm{pH}$ 7.4) were added. Then, $100 \mu \mathrm{L}$ of the fluorescein solution was added, and the plate was placed on the microplate reader, which injected 50 $\mu \mathrm{L}$ of the AAPH solution at $37^{\circ} \mathrm{C}$. The fluorescence reading was performed until the initial fluorescence value of $5 \%$ was reached. For the calculations, the area under the curve (AUC) of the samples was used, and the results were expressed as TEAC (Trolox Equivalent Antioxidant Capacity) in mmoles TE $\mathrm{g}^{-1}$ of protein.

\section{Statistical Analysis}

Analysis of variance (ANOVA) with significant of $5 \%$ was performed to determinate differences among treatments, then the Tukey test was carried out for mean comparisons for at a significant level of $P<0.05$.

\section{RESULTS AND DISCUSSION}

In this study, HHP was used to assist the hydrolysis process as a pre-treatment of whey (PT) or HHP-assisted hydrolysis (AH). As a control, conventional hydrolysis $(\mathrm{CH})$ was performed in untreated whey at room pressure $(0.1 \mathrm{MPa})$. The pressure and time used in the treatments varied according to the experimental design, exhibited in Table 1. Tables 2, 3 and 4 shows the effects of the independent variables (pressure and time) on the dependent variables (soluble proteins, aromatic amino acids, and in vitro antioxidant capacity).

\section{Influence of HHP on the chemical properties of hydrolyzed WPC}

The chemical properties of the hydrolysates were evaluated for the content of soluble proteins, aromatic amino acids, and chromatographic profiles.

The content of soluble proteins was monitored for 240 minutes in the $\mathrm{CH}$ and $\mathrm{PT}$ treatments (Figure 1A). In general, the variables time and pressure were not significant $(P>0.05)$ in reducing the soluble protein content when HHP was used in PT. The exception was for the time of 240 minutes of hydrolysis, in which the pressure had a negative effect $(P<0.05)$ and time a positive effect $(P$ $<0.05$ ), suggesting the use of higher pressure to obtain a greater reduction in soluble protein content (Tables 2 and 3). Although in all experiments a reduction in the soluble protein content is observed, which indicates peptic hydrolysis, in the experiment in which the pressure of $400 \mathrm{MPa}$ for 35 minutes (PT4) was used, the reduction of soluble proteins was $25 \%$ after 120 minutes of hydrolysis, while the reduction of soluble proteins in $\mathrm{CH}$ was $20 \%$ after 240 minutes, indicating that the use of HHP in this condition decreased the hydrolysis time by $50 \%$. The PT1, PT2, and PT5 experiments showed no significant difference $(P>$ 0.05 ) in relation to $\mathrm{CH}$, which can be by the structural rearrangement of proteins, resuming their structural conformation after depressurization. The time it takes for proteins to refold is entirely dependent on the level of pressure, $\mathrm{pH}$, and time applied in the process (AMBROSI et al., 2016; HUPPERTZ et al., 2006; HUPPERTZ et al., 2004). After decompression of the system, the restructuring of $\beta-\mathrm{Lg}$ occurs quickly at acidic $\mathrm{pH}$, especially when pressures below $300 \mathrm{MPa}$ are used, which may justify the lack of effect of HHP on PT, suggesting the need for higher pressures for a lingering effect after the system is depressurized (BELLOQUE et al., 2007).

Figure 1B shows the values of aromatic amino acids released along the hydrolysis processes. In all treatments, the rate of release of amino acids increased throughout the hydrolysis process, but PTs experiments showed higher values than $\mathrm{CH}$. Regardless, HHP showed an effect only in the 180 and 240 minutes of hydrolysis, where pressure and time had a significant negative quadratic effect $(P<$ 0.05 ) (Table 3), which means that the use of lower pressures for a shorter time in a pre-treatment process favored the release of amino acids during hydrolysis. 
Table 2 - Regression coefficients and ANOVA of fitted model for antioxidant capacities (ABTS, ORAC), soluble protein and aromatic amino acid assays of the pre-treated WPC at different hydrolysis times $(0,1$, and 60 minutes).

\begin{tabular}{|c|c|c|c|c|c|c|c|c|}
\hline \multirow{3}{*}{ Term } & \multicolumn{2}{|c|}{$\mathrm{ABTS}^{\mathrm{c}}$} & \multicolumn{2}{|c|}{$\mathrm{ORAC}^{\mathrm{d}}$} & \multicolumn{2}{|c|}{ Soluble Protein } & \multicolumn{2}{|c|}{ Aromatic Amino Acid } \\
\hline & \multicolumn{2}{|c|}{$\begin{array}{c}\text { R2 }=0.9987 ; \\
\text { R2Adj }=0.9937\end{array}$} & \multicolumn{2}{|c|}{$\begin{array}{c}\text { R2 }=0.9985 \\
\text { R2Adj }=0.9926\end{array}$} & \multicolumn{2}{|c|}{$\begin{array}{c}\text { R2 }=0.9344 ; \\
\text { R2Adj }=0.67176\end{array}$} & \multicolumn{2}{|c|}{$\mathrm{R} 2=0.9344 ; \mathrm{R} 2 \mathrm{Adj}=0.6718$} \\
\hline & Coeff. & $\mathrm{P}$ & Coeff. & $\mathrm{p}$ & Coeff. & $\mathrm{p}$ & Coeff. & $\mathrm{p}$ \\
\hline Mean/Interc. & 48.20 & 0.003 & 203.84 & 0.010 & 8.322 & 0.001 & 0.039 & 0.009 \\
\hline (1)Pressure(L) & -1.32 & 0.135 & -52.46 & 0.046 & 0.148 & 0.092 & 0.000 & 0.633 \\
\hline Pressure(Q) & -4.66 & 0.033 & -68.40 & 0.030 & 0.200 & 0.059 & -0.005 & 0.074 \\
\hline (2)Time (L) & -3.08 & 0.058 & 55.29 & 0.043 & 0.025 & 0.448 & -0.005 & 0.088 \\
\hline $1 \mathrm{~L}$ by $2 \mathrm{~L}$ & 0.95 & 0.184 & -80.28 & 0.030 & 0.059 & 0.225 & -0.007 & 0.065 \\
\hline \multicolumn{9}{|c|}{ - } \\
\hline \multirow{3}{*}{ Term } & \multicolumn{2}{|c|}{$\mathrm{ABTS}^{\mathrm{c}}$} & \multicolumn{2}{|c|}{ ORAC ${ }^{\mathrm{d}}$} & \multicolumn{2}{|c|}{ Soluble protein } & \multicolumn{2}{|c|}{ Aromatic Amino Acid } \\
\hline & \multicolumn{2}{|c|}{$\begin{array}{c}\text { R2 }=0.9987 ; \\
\text { R2Adj: }=0.9937\end{array}$} & \multicolumn{2}{|c|}{$\begin{array}{c}\text { R2 }=0.9985 ; \\
\text { R2Adj }=0.9926\end{array}$} & \multicolumn{2}{|c|}{$\begin{array}{c}\mathrm{R} 2=0.9344 ; \\
\mathrm{R} 2 \mathrm{Adj}=0.6718\end{array}$} & \multicolumn{2}{|c|}{$\mathrm{R} 2=0.9778 ; \mathrm{R} 2 \mathrm{Adj}=0.8888$} \\
\hline & Coeff. & $\mathrm{P}$ & Coeff. & $\mathrm{p}$ & Coeff. & $\mathrm{p}$ & Coeff. & $\mathrm{p}$ \\
\hline Mean/Interc. & 51.05 & 0.002 & 294.26 & 0.013 & 9.900 & 0.005 & 0.124 & 0.019 \\
\hline (1)Pressure(L) & -0.88 & 0.150 & -100.35 & 0.046 & -0.141 & 0.376 & -0.018 & 0.158 \\
\hline Pressure(Q) & -3.88 & 0.030 & -96.38 & 0.041 & -0.176 & 0.278 & -0.015 & 0.160 \\
\hline (2)Time (L) & -3.68 & 0.037 & 95.81 & 0.048 & 0.212 & 0.267 & -0.003 & 0.638 \\
\hline $1 \mathrm{~L}$ by $2 \mathrm{~L}$ & -1.08 & 0.123 & -57.31 & 0.079 & -0.145 & 0.367 & -0.016 & 0.174 \\
\hline \multicolumn{9}{|c|}{ - } \\
\hline \multirow{3}{*}{ Term } & \multicolumn{2}{|c|}{$\mathrm{ABTS}^{\mathrm{c}}$} & \multicolumn{2}{|c|}{ ORAC } & \multicolumn{2}{|c|}{ Soluble protein } & \multicolumn{2}{|c|}{ Aromatic Amino Acid } \\
\hline & \multicolumn{2}{|c|}{$\begin{array}{c}\text { R2 }=0.9987 \\
\text { R2Adj }=0.9937\end{array}$} & \multicolumn{2}{|c|}{$\begin{array}{c}\text { R2 }=0.9985 ; \\
\text { R2Adj }=0.9926\end{array}$} & \multicolumn{2}{|c|}{$\begin{array}{c}\mathrm{R} 2=0.9344 ; \\
\text { R2Adj }=0.6718\end{array}$} & \multicolumn{2}{|c|}{$\mathrm{R} 2=0.9344 ; \mathrm{R} 2 \mathrm{Adj}=0.6718$} \\
\hline & Coeff. & $\mathrm{P}$ & Coeff. & $\mathrm{p}$ & Coeff. & $\mathrm{p}$ & Coeff. & $\mathrm{p}$ \\
\hline Mean/Interc. & 153.29 & 0.006 & 1526.62 & 0.013 & 25.260 & 0.010 & 0.932 & 0.044 \\
\hline (1)Pressure(L) & -13.15 & 0.078 & -749.63 & 0.032 & -2.509 & 0.119 & -0.334 & 0.148 \\
\hline Pressure(Q) & -18.03 & 0.050 & -165.69 & 0.125 & -0.001 & 0.998 & -0.004 & 0.965 \\
\hline (2)Time (L) & -5.45 & 0.185 & 456.19 & 0.053 & -0.876 & 0.317 & 0.148 & 0.312 \\
\hline $1 \mathrm{~L}$ by $2 \mathrm{~L}$ & 1.25 & 0.583 & -234.65 & 0.102 & -1.130 & 0.254 & 0.290 & 0.170 \\
\hline
\end{tabular}

${ }^{\mathrm{a}} \mathrm{HHP}$ - High hydrostatic pressure. ${ }^{\mathrm{b}} \mathrm{WPC}$ - Whey protein concentrate. ${ }^{\mathrm{c}} \mathrm{ABTS}$ assay $\left(\mathrm{ABTS}^{+}\right.$- 2,2'-azinobis 3 - ethylbenzothiazoline 6 sulfonate). ${ }^{\mathrm{d}}$ ORAC assay (Oxygen Radical Absorbance Capacity).

Thus, the highest levels of amino acids were obtained in PT1 and PT2, being significantly different $(P<$ 0.05) from PT3, PT4, and PT5 (Figure 1B).

In HHP-assisted hydrolysis, enzymatic reactions occur simultaneously with the application of pressure for a stipulated time. In this process, the pressure had no significant influence $(P>0.05)$ on the reduction of soluble proteins, but the time was significant $(P<0.05)$ (Table 4$)$. Thus, the reduction in the soluble protein content was greater in the treatments of longer time ( $35 \mathrm{~min}$ ), regardless of the applied pressure (100 or $400 \mathrm{MPa})$, as observed for $\mathrm{AH} 3$ and $\mathrm{AH} 4$, which showed a 35 and $25 \%$ reduction in soluble proteins, respectively (Figure 1C), with significant gain compared to $\mathrm{CH}$, which showed a reduction of $20 \%$. The HHP-assisted treatment was more efficient to reduce the soluble protein content in less time when compared to the $\mathrm{CH}$ process, which showed a $20 \%$ reduction in proteins after 240 minutes of hydrolysis. Regarding the release of aromatic amino acids (Figure 1D), pressure and time had no significant effect $(P>0.05)$, but higher levels were found in the longer, AH3 (100 MPa / $35 \mathrm{~min})$ and AH5 (250/ $20 \mathrm{~min})$. These findings are in line with the observations made by ZHANG et al., (2012), who found that the pressurization time was more significant in increasing the degree of hydrolysis than the pressure level. The folding changes that occur during the HHP process cause more protein cleavage sites to be exposed, and allow the enzymes present in 
Table 3 - Regression coefficients and ANOVA of fitted model for antioxidant capacities (ABTS, ORAC), soluble protein and aromatic amino acid assays at different hydrolysis times (120, 180, and 240 minutes).

\begin{tabular}{|c|c|c|c|c|c|c|c|c|}
\hline \multirow{3}{*}{ Term } & \multirow{2}{*}{\multicolumn{2}{|c|}{$\begin{array}{c}\text { ABTS }^{\mathrm{c}} \\
\mathrm{R} 2=0.9999 ; \\
\mathrm{R} 2 \mathrm{Adj}=0.9996\end{array}$}} & \multirow{2}{*}{\multicolumn{2}{|c|}{$\begin{array}{c}\text { ORAC }^{\mathrm{d}} \\
\text { R2 }=0.94227 ; \\
\text { R2Adj }=0.7113\end{array}$}} & \multirow{2}{*}{\multicolumn{2}{|c|}{$\begin{array}{l}\text { Soluble protein } \\
\text { R2 }=0.9848 ; \\
\text { R2Adj }=0.9240\end{array}$}} & \multirow{2}{*}{\multicolumn{2}{|c|}{$\begin{array}{c}\text { Aromatic Amino Acid } \\
\mathrm{R} 2=0.9416 ; \mathrm{R} 2 \mathrm{Adj}=0.7081\end{array}$}} \\
\hline & & & & & & & & \\
\hline & Coeff. & $\mathrm{P}$ & Coeff. & $\mathrm{p}$ & Coeff. & $\mathrm{p}$ & Coeff. & $\mathrm{p}$ \\
\hline Mean/Interc. & 48.09 & 0.001 & 601.40 & 0.038 & 7.665 & 0.008 & 0.478 & 0.020 \\
\hline (1)Pressure(L) & -5.12 & 0.006 & -102.43 & 0.255 & -0.561 & 0.136 & -0.026 & 0.401 \\
\hline Pressure(Q) & -0.98 & 0.027 & -10.30 & 0.830 & -0.025 & 0.852 & -0.028 & 0.337 \\
\hline (2)Time (L) & -0.88 & 0.034 & 82.41 & 0.309 & -0.422 & 0.178 & -0.062 & 0.185 \\
\hline $1 \mathrm{~L}$ by $2 \mathrm{~L}$ & 0.38 & 0.078 & -115.68 & 0.229 & -0.681 & 0.112 & 0.006 & 0.791 \\
\hline \multirow{4}{*}{ Term } & & $\mathrm{HHP}^{\mathrm{a}}-\mathrm{p}$ & eatment (1 & e $180 \mathrm{~m}$ & ites of pr & s) -----. & ------- & 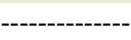 \\
\hline & \multicolumn{2}{|c|}{$\mathrm{ABTS}^{\mathrm{c}}$} & \multicolumn{2}{|c|}{ ORAC $^{\mathrm{d}}$} & \multicolumn{2}{|c|}{ Soluble protein } & \multicolumn{2}{|c|}{ Aromatic Amino Acid } \\
\hline & \multicolumn{2}{|c|}{$\begin{array}{c}\mathrm{R} 2=0.9998 ; \\
\text { R2Adj }=0.9989\end{array}$} & \multicolumn{2}{|c|}{$\begin{array}{c}\text { R2 }=0.9999 ; \\
\text { R2Adj }=0.9997\end{array}$} & \multicolumn{2}{|c|}{$\begin{array}{c}\text { R2 }=0.9948 ; \\
\text { R2Adj }=0.9738\end{array}$} & \multicolumn{2}{|c|}{$\mathrm{R} 2=0.9990 ; \mathrm{R} 2 \mathrm{Adj}=0.9950$} \\
\hline & Coeff. & $\mathrm{P}$ & Coeff. & $\mathrm{p}$ & Coeff. & $\mathrm{p}$ & Coeff. & $\mathrm{p}$ \\
\hline Mean/Interc. & 50.78 & 0.001 & 630.34 & 0.002 & 7.443 & 0.004 & 0.482 & 0.005 \\
\hline (1)Pressure(L) & -3.98 & 0.015 & -125.93 & 0.014 & -0.517 & 0.079 & -0.058 & 0.051 \\
\hline Pressure(Q) & -3.44 & 0.015 & -86.59 & 0.018 & -0.099 & 0.326 & -0.080 & 0.032 \\
\hline (2)Time (L) & -1.35 & 0.044 & 220.59 & 0.008 & 0.099 & 0.367 & -0.095 & 0.031 \\
\hline $1 \mathrm{~L}$ by $2 \mathrm{~L}$ & -2.75 & 0.022 & -208.96 & 0.008 & -0.700 & 0.058 & -0.013 & 0.218 \\
\hline \multicolumn{9}{|c|}{----------------------------------------HHPa } \\
\hline \multirow{3}{*}{ Term } & \multicolumn{2}{|c|}{$\mathrm{ABTS}^{\mathrm{c}} \mathrm{r}$} & \multicolumn{2}{|c|}{ ORAC $^{\mathrm{d}}$} & \multicolumn{2}{|c|}{ Soluble protein } & \multicolumn{2}{|c|}{ Aromatic Amino Acid } \\
\hline & \multicolumn{2}{|c|}{$\begin{array}{c}\text { R2 }=0.9993 ; \\
\text { R2Adj }=0.9962\end{array}$} & \multicolumn{2}{|c|}{$\begin{array}{c}\text { R2 }=0.9956 ; \\
\text { R2Adj=0.9781 }\end{array}$} & \multicolumn{2}{|c|}{$\begin{array}{c}\text { R2 }=0.9994 ; \\
\text { R2Adj }=0.9972\end{array}$} & \multicolumn{2}{|c|}{$\mathrm{R} 2=0.9987 ; \mathrm{R} 2 \mathrm{Adj}=0.9933$} \\
\hline & Coeff. & $\mathrm{P}$ & Coeff. & $\mathrm{p}$ & Coeff. & $\mathrm{p}$ & Coeff. & $\mathrm{p}$ \\
\hline Mean/Interc. & 48.83 & 0.001 & 606.37 & 0.016 & 6.768 & 0.001 & 0.573 & 0.004 \\
\hline (1)Pressure(L) & -1.63 & 0.037 & -100.11 & 0.116 & -0.426 & 0.025 & -0.055 & 0.056 \\
\hline Pressure(Q) & -1.68 & 0.031 & -55.58 & 0.178 & -0.051 & 0.179 & -0.061 & 0.044 \\
\hline (2)Time (L) & -1.63 & 0.037 & 179.59 & 0.065 & 0.291 & 0.037 & -0.097 & 0.032 \\
\hline $1 \mathrm{~L}$ by $2 \mathrm{~L}$ & -1.63 & 0.037 & -176.08 & 0.067 & -0.458 & 0.023 & -0.003 & 0.623 \\
\hline
\end{tabular}

${ }^{\mathrm{a}} \mathrm{HHP}$ - High hydrostatic pressure. ${ }^{\mathrm{c}} \mathrm{ABTS}$ assay $\left(\mathrm{ABTS}^{+}-2,2^{\prime}\right.$-azinobis 3-ethylbenzothiazoline 6-sulfonate). ${ }^{\mathrm{d}} \mathrm{ORAC}$ assay $(\mathrm{Oxygen}$ Radical Absorbance Capacity).

the process to access these sites that were not previously possible, due to the compact structure of whey proteins. Also, HHP can result in enzymatic activation, which can increase catalytic power and promote a higher degree of hydrolysis (DUFOUR et al., 1995; HENDRICKX et al., 1998; MENEZES et al., 2008; ZHANG et al., 2012).

Figures $2 \mathrm{~A}, \mathrm{~B}$, and $\mathrm{C}$ show the peptide profiles of the hydrolysates $\mathrm{CH}, \mathrm{PT}$, and $\mathrm{AH}$, respectively. In general, the peptide profiles of the hydrolysate $\mathrm{CH}$ and hydrolysates PTs were similar, although it is possible to observe a greater intensity of some peaks in the chromatograms of the experiments in which the HHP was used. Figures $2 \mathrm{~A}$ and $\mathrm{B}$ show that rapid and efficient hydrolysis of $\alpha-\mathrm{La}$, regardless of the time and pressure used in PT. Typically, pepsin-mediated hydrolysis is similar to promoting fast and efficient $\alpha$-La hydrolysis and partial $\beta$-Lg hydrolysis (OZORIO et al., 2019). $\alpha$-La is less stable in acidic $\mathrm{pH}$, which makes it more prone to peptic hydrolysis. The opposite happens with native $\beta-\mathrm{Lg}$, which has a compact structure in acidic $\mathrm{pH}$ where amino acid residues are buried inside the molecule and inaccessible to the enzyme. However, in the treatment in which a pressure of $400 \mathrm{MPa}$ was used for 35 minutes (PT4), the reduction in its peak area was $76 \%$ after 180 minutes of hydrolysis, while in the $\mathrm{CH}$ experiment the reduction in the area of $\beta$-Lg was of only $29 \%$ after the same reaction period. The use of $400 \mathrm{MPa}$ for 35 minutes was enough to cause changes that persisted after depressurization, facilitating the access of pepsin to specific points of this protease. 
Table 4 - Regression coefficients and ANOVA of fitted model for antioxidant capacities (ABTS, ORAC), soluble protein and aromatic amino acid assays of the assisted hydrolysis.

\begin{tabular}{|c|c|c|c|c|c|c|c|c|}
\hline \multirow[t]{3}{*}{ Term } & \multicolumn{2}{|c|}{$\mathrm{ABTS}^{\mathrm{c}}$} & \multicolumn{2}{|c|}{$\mathrm{ORAC}^{\mathrm{d}}$} & \multicolumn{2}{|c|}{ Soluble protein } & \multicolumn{2}{|c|}{ Aromatic Amino Acid } \\
\hline & \multicolumn{2}{|c|}{$\begin{array}{c}\text { R2=0.9884; } \\
\text { R2Adj:0.9425 }\end{array}$} & \multicolumn{2}{|c|}{$\begin{array}{c}\text { R2=0.9936; } \\
\text { R2Adj:0.9679 }\end{array}$} & \multicolumn{2}{|c|}{$\begin{array}{c}\text { R2=0.9991; } \\
\text { R2Adj:0.9955 }\end{array}$} & \multicolumn{2}{|c|}{$\mathrm{R} 2=0.9994 ; \mathrm{R} 2 \mathrm{Adj}: 0.996$} \\
\hline & Coeff. & $\mathrm{P}$ & Coeff. & $\mathrm{p}$ & Coeff. & $\mathrm{p}$ & Coeff. & $\mathrm{p}$ \\
\hline Mean/Interc. & 54.94 & 0.004 & 380.94 & 0.014 & 9.76 & 0.003 & 9.76 & 0.003 \\
\hline (1)Pressure(L) & -3.20 & 0.089 & 21.46 & 0.286 & 0.51 & 0.079 & 0.51 & 0.079 \\
\hline Pressure(Q) & -1.08 & 0.219 & 40.87 & 0.137 & -0.01 & 0.909 & -0.01 & 0.909 \\
\hline (2)Time (L) & 0.53 & 0.445 & 106.37 & 0.062 & -2.06 & 0.020 & -2.06 & 0.020 \\
\hline $1 \mathrm{~L}$ by $2 \mathrm{~L}$ & 2.27 & 0.124 & 49.79 & 0.130 & 0.05 & 0.558 & 0.05 & 0.558 \\
\hline
\end{tabular}

${ }^{\mathrm{a}} \mathrm{HHP}$ - High hydrostatic pressure. ${ }^{\mathrm{c}} \mathrm{ABTS}$ assay $\left(\mathrm{ABTS}^{+}-2,2^{\prime}\right.$-azinobis 3-ethylbenzothiazoline 6-sulfonate). ${ }^{\mathrm{d} O R A C}$ assay (Oxygen Radical Absorbance Capacity).

In high pressure-assisted (HA) hydrolysis of WPC (Fig. 2C), the chromatograms reinforce the observations that time was the response variable that significantly influenced the reduction of soluble proteins. In chromatograms where the pressures of $100 \mathrm{MPa}$ (AH1) and $400 \mathrm{MPa}$ (AH2) were applied for 5 minutes, the peak reduction for $\alpha$-La was 2 and $4 \%$, and for $\beta-\operatorname{Lg} 38 \%$ and $37 \%$, respectively. On the
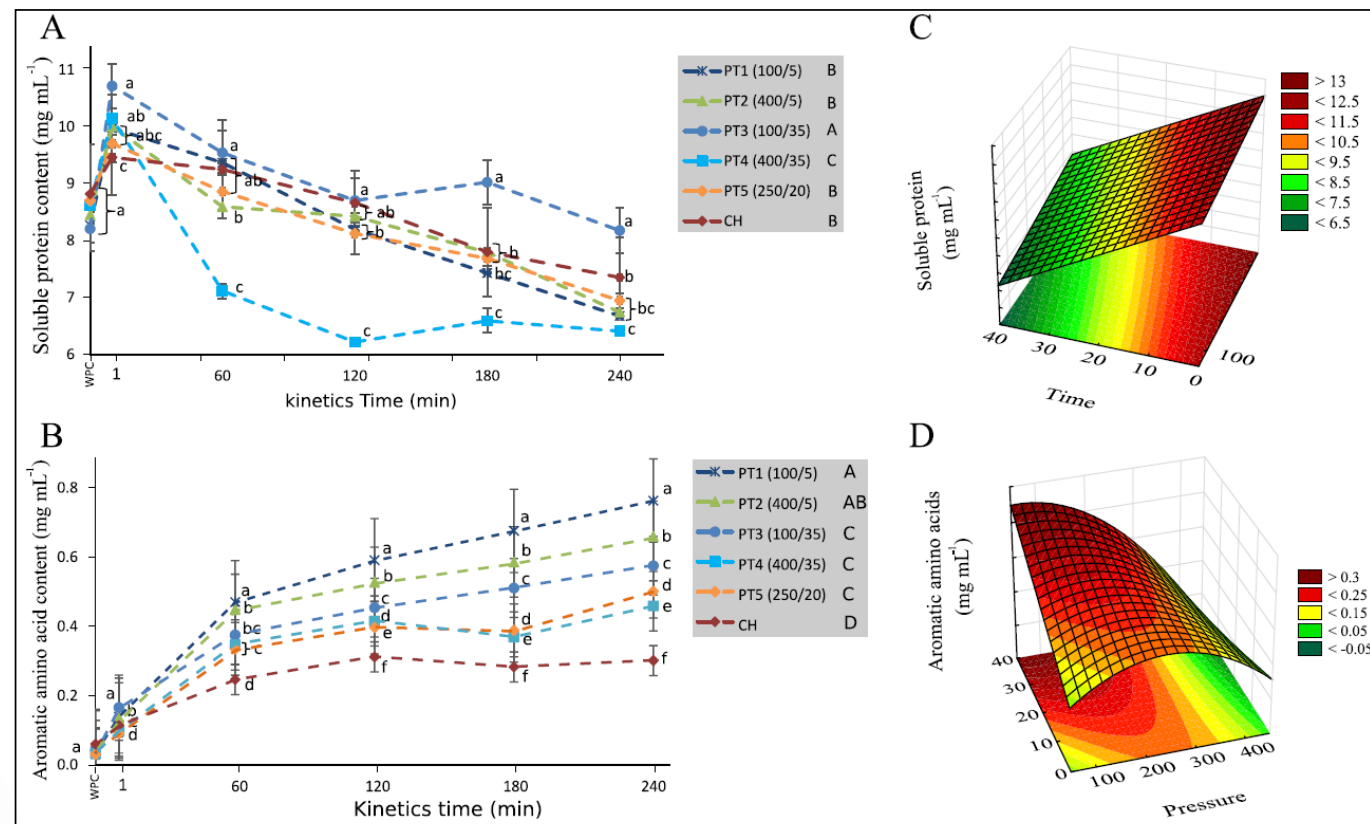

$\mathrm{D}$

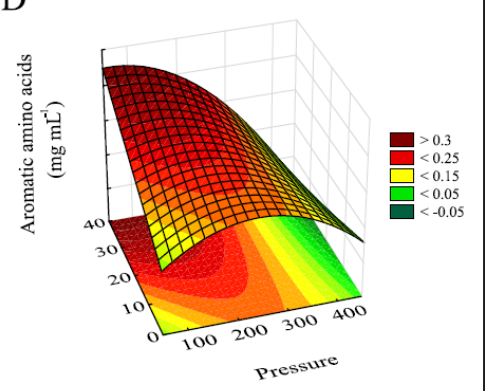

Figure 1 - Whey protein hydrolysis curves after conventional hydrolysis $(\mathrm{CH})$ and HHP-pretreated (PT) evaluated by (A) soluble protein content ; (B) aromatic amino acid content, at the different times of process and response surface graphs for the effect of HHP on assisted hydrolysis (AH) in the different conditions of the experimental planning for (C) soluble protein content and (D) aromatic amino acid content. PT1 $=100$ $\mathrm{MPa} / 35$ minutes; PT2 $=400 \mathrm{MPa} / 5$ minutes; PT3 $=100 \mathrm{MPa} / 35$ minutes; PT4 $=400 \mathrm{MPa} / 35$ minutes; PT5 $=250 \mathrm{MPa} / 20$ minutes. Treatments with different lowercase letters, at similar hydrolysis times, are significantly different from each other $(P \leq 0.05)$. Capital letters next to the legend indicate statistical difference $(P \leq 0.05)$ between treatments. 


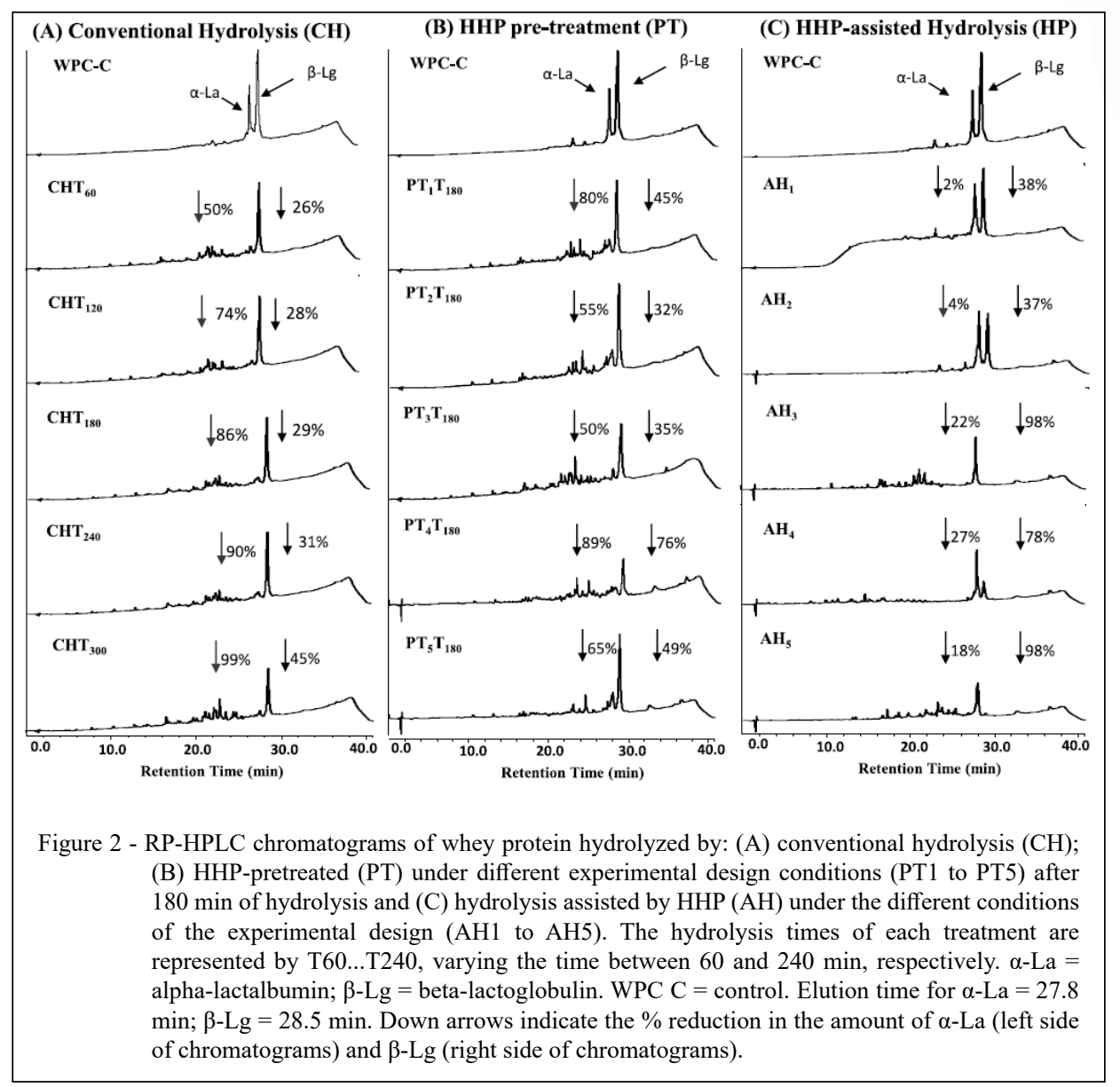

other hand, when the longest process time was used, regardless of whether the pressure was $100 \mathrm{MPa}, 250$ $\mathrm{MPa}$, or $400 \mathrm{MPa}$, the reductions in the peak area for $\beta$-Lg were 98,98 , and $78 \%$, respectively. Similar responses were observed by FRANCK et al., (2018), who showed that, in assisted hydrolysis, time was also important for the process, but emphasized that a combination of higher pressure for a longer period is ideal. However, it must be taken into account that the use of pressures above $300 \mathrm{MPa}$ can cause conformational changes in the enzymes that could also result in a decreased enzyme activity (PEÑAS, et al., 2006; YOO et al., 2017; ZHANG et al., 2012).

Furthermore, $\alpha$-La was more susceptible to peptic hydrolysis in the $\mathrm{PT}$ and $\mathrm{CH}$ experiments, and $\beta$-Lg became more susceptible in the AH experiment, as previously discussed. This behavior may be related to the different barosensitivity of the proteins to treatment with HHP (AMBROSI et al., 2016). Among the proteins, $\beta$ - $\mathrm{Lg}$ is the most sensitive one to pressure, as it has four disulfide bonds, while $\alpha$-La is the most resistant because as it has only two disulfide bonds (GOYAL et al., 2013). The fact that $\beta$-Lg has a higher barosensitivity makes HHP-assisted an even more interesting tool to be applied since the catalytic resistance of this protein is very high under ambient pressure conditions. Thus, the use of $100 \mathrm{MPa}$ for 35 minutes might be the best combination choice for enhancing whey hydrolysis considering the discussed chemical changes.

Influence of HHP on the antioxidant capacity of hydrolyzed WPC

The HHP effect used in the pre-treatment and the assisted hydrolysis on the antioxidant capacity of the hydrolysates were also evaluated using the ABTS and ORAC assays, which show the antioxidant capacity through different mechanisms of action, as ABTS that evaluates the ability of molecules to donate electrons or hydrogen, resulting 
in the reduction of the ABTS radical and ORAC measures the ability of antioxidants in the sample to prevent oxidative damage by breaking the chain of peroxyl radicals (ZULUETA et al., 2009).

Figure $3 \mathrm{~A}$ shows the ABTS values for the PTs and $\mathrm{CH}$ experiments. In the ABTS assay, peptic hydrolysis was not able to increase the antioxidant capacity of the hydrolyzate in relation to WPC. On the other hand, the use of HHP as a pre-treatment caused an increase in the antioxidant capacity in all conditions evaluated. In the pre-treatment, the pressure and time used in the process had a significant negative effect $(P<0.05)$ in the different hydrolysis times evaluated (Tables 2 and 3), which suggests that the use of milder pressures and times in the pre-treatment favors a hydrolysate with greater antioxidant capacity. All PTs experiments showed a significant difference $(P<0.05)$ to the antioxidant capacity of the $\mathrm{CH}$ experiment. The highest ABTS values were obtained for pre-treated hydrolysates at the pressures of 100 and $400 \mathrm{MPa}$ for 5 minutes (PT1 and PT2), and $100 \mathrm{MPa}$ for 35 minutes (PT3), with
61.72, 54.45, and 57.25 $\mu$ mols $\mathrm{TE} \mathrm{g}^{-1}$ of proteins, respectively, after 60 minutes of hydrolysis. These values represented an increase of $92 \%$ on the in vitro antioxidant capacity when compared to those obtained in the $\mathrm{CH}$ experiment.

As for HHP-assisted hydrolysis, the time and pressure parameters had no significant effect $(P>0.05)$ on the antioxidant capacity of the hydrolysates (Table 4). The ABTS values between treatments ranged from 52.85 to $60.59 \mu$ mols $\mathrm{TE} \mathrm{g}^{-1}$ of proteins (Figure 3C). These values also represent an increase of approximately $90 \%$ in the in vitro antioxidant capacity in relation to those verified for $\mathrm{CH}$, in which the highest value observed was $34.25 \mu$ mols TE g-1 after 240 minutes of hydrolysis.

These results indicate that the use of HHP as a pre-treatment (PT) or simultaneously with hydrolysis (AH) was sufficient to promote conformational changes that allowed greater interaction between chemical groups capable of promoting the donation of electrons in a redox reaction and can act as molecules of greater antioxidant capacity, according to the ABTS assay.
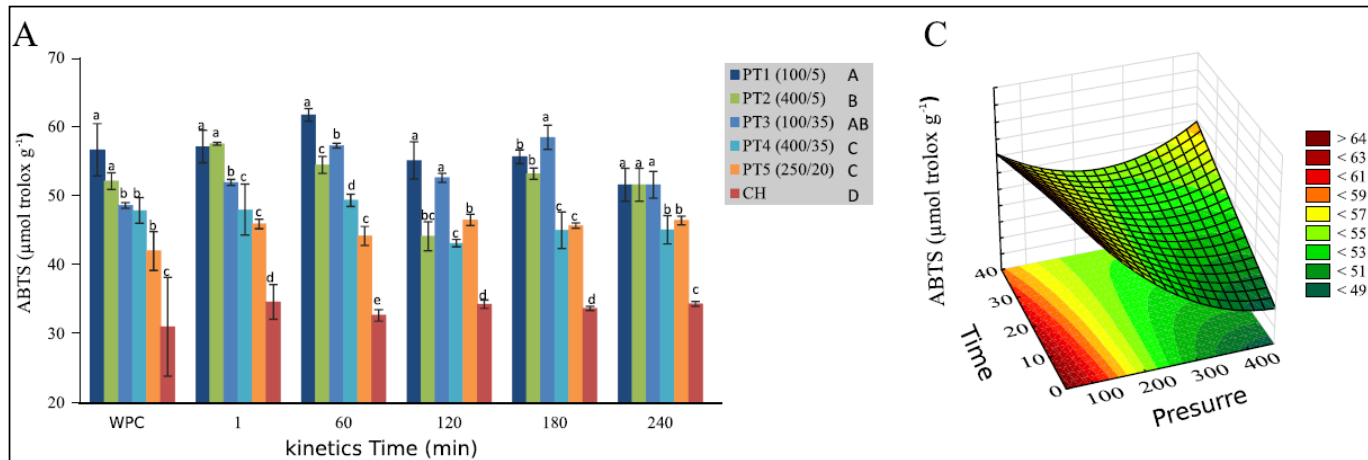

B

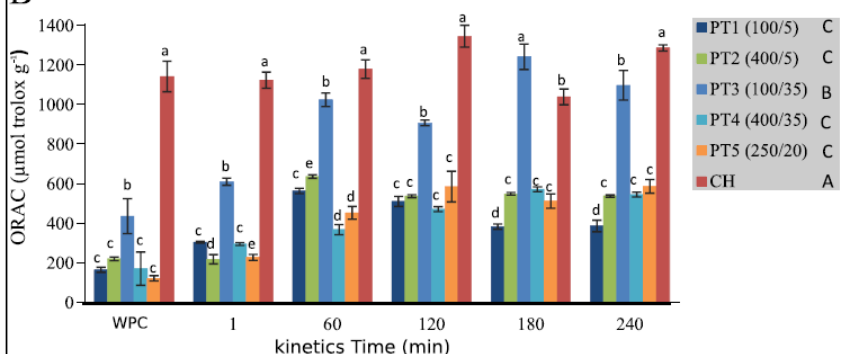

$\mathrm{D}$

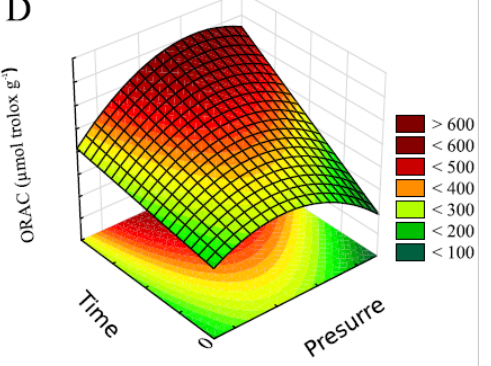

Figure 3 - In vitro Antioxidant capacity of whey protein hydrolysates after conventional hydrolysis $(\mathrm{CH})$ and HHPpretreated (PT) evaluated by (A) ABTS assay, (B) ORAC assay, at the different process time. (C) response surface graphs for the effect of HHP on assisted hydrolysis (AH) of the WPC in the different conditions of the experimental planning for ABTS, and (D) ORAC responses. PT1 $=100 \mathrm{MPa} / 35$ minutes; $\mathrm{PT} 2=400 \mathrm{MPa} / 5$ minutes; PT3 $=100 \mathrm{MPa} / 35$ minutes; PT4 $=400 \mathrm{MPa} / 35$ minutes; PT $5=250 \mathrm{MPa} / 20$ minutes. Treatments with different lowercase letters, at similar hydrolysis times, are significantly different from each other $(P \leq$ $0.05)$. Capital letters next to the legend indicate statistical difference $(P \leq 0.05)$ between treatments. 
In the ORAC assay, the HHP pre-treatment showed that the pressure had a significant positive quadratic effect $(P<0.05)$ for all hydrolysis times, and the variable time had a significant negative linear effect $(P<0.05)$ for all hydrolysis times, except 60 min (Tables 2 and 3). ORAC values are shown in Figure 3B, and unlike ABTS, hydrolysis contributed to the increase in antioxidant activity. However, despite the effect of pressure and time, the pretreatment with HHP did not increase the proton donor capacity of the hydrolysates in relation to $\mathrm{CH}$, except in PT3 (100MPa / $35 \mathrm{~min}$ ), which showed the highest activity value, $1243.53 \mu$ mols of $\mathrm{TE}^{-1}$ protein after 180 minutes of reaction. Regarding HHP-assisted hydrolysis, the levels of pressure and time used during the process did not have a significant effect $(P>0.05)$ on the in vitro antioxidant capacity by ORAC (Table 4). The best result presented 528.77 and $477.84 \mu \mathrm{mols} \mathrm{TE} \mathrm{g}^{-1}$ protein (AH4 - 400MPa / 35 $\mathrm{min})$, a value close to the control $(\mathrm{CH}-515.13 \mu \mathrm{mols}$ TE $\mathrm{g}^{-1}$ protein), after 240 minutes of hydrolysis. However, in other studies, it was found that pressure and time can also affect these properties, especially when hydrolysis is performed simultaneously with HHP, and the use of pressures between 100 and 300 $\mathrm{MPa}$ might be more indicated (GARCIA-MORA et al., 2015 e ZHANG et al., 2012).

In general, the use of HHP as a pretreatment or in an assisted form can be employed to increase the antioxidant capacity of hydrolysates. However, studying the level of pressure and time in the treatment is essential. The different levels of pressure used can affect distinctively the mechanisms of action of peptides formed during hydrolysis (GIRGIH et al., 2015). Also, the antioxidant capacity of hydrolysates has been linked to a joint action between peptides and free amino acids. HHP can promote structural changes that favor the production of peptides with antioxidant capacity, but it can also favor the increase in the release of amino acids, as observed in this study (Figure $1 \mathrm{~B}$ ), which may be related to the increase in the antioxidant capacity of the hydrolysate pre-treated with HHP (CORROCHANO et al., 2019; ISKANDAR et al., 2015; PICCOLOMINI et al., 2012; POWER-GRANT et al., 2015; VILELA et al., 2006).

Thus, evaluating only the results for the antioxidant capacity (Figure $3 \mathrm{~A}, \mathrm{~B}, \mathrm{C}$, and D), the treatment with HHP in experiments PT1 and PT2 (pretreatment), and AH4 and AH5 (assisted hydrolysis), could be used to obtain hydrolysates with greater antioxidant capacity. However, taking into account the chemical properties (Figure 1A, B, C, and D), the most suitable treatments would be PT4 and AH1, as they presented greater antioxidant capacity and a higher degree of protein hydrolysis when compared to the $\mathrm{CH}$ treatment.

\section{CONCLUSION}

According to the experimental data obtained, the present study demonstrated that HHP technology can be used to increase the hydrolysis of whey proteins when pepsin is used. In HHP hydrolysis-assisted process, time was the variable that showed significant influence in the enzymatic reaction, where the highest proteolysis with increasing in vitro antioxidant capacity was observed at $100 \mathrm{MPa}$ for 35 minutes. Moreover, the results demonstrated that pressurizing whey proteins can unfold $\beta$-lactoglobulin making it more susceptible to peptic hydrolysis, and in general, it contributes to the increase in the antioxidant capacity of hydrolysates. Therefore, the use of high hydrostatic pressure in an assisted manner provided promising prospects for application in the food industry.

\section{ACKNOWLEDGEMENTS}

This study was supported by the Brazilian agencies Fundação Carlos Chagas Filho de Amparo à Pesquisa do Estado do Rio de Janeiro (FAPERJ, Grant number E-26/110.631/2012), Coordenação de Aperfeiçoamento de Pessoal de Nivel Superior (CAPES) and Empresa Brasileira de Pesquisa Agropecuária (EMBRAPA). The authors thank Alibra Ingredientes Ltda for supplying WPC, and Bela Vista Produtos Enzimáticos for supplying the commercial pepsin.

\section{DECLARATION OF CONFLICTS OF INTERESTS}

The authors declare that there is no conflict of interest. The funding entities had no influence on the study design; nor in the collection, analysis or interpretation of the data; in the writing of the manuscript, nor in the decision to publish the results.

\section{AUTHORS' CONTRIBUTIONS}

Ana Paula Miguel Landim executed all the experiments, drafted and interpreted the manuscript. Davy William Hidalgo Chávez performed and interpreted the statistical analyzes. Jeane Santos da Rosa coordinated and performed the antioxidant analysis. Caroline Mellinger-Silva designed the study and interpreted the results. Amauri Rosental supervised the study. All authors critically reviewed the manuscript and approved a final version.

\section{REFERENCES}

ABADÍA-GARCÍA, L. et al. Impact of ultrasound pretreatment on whey protein hydrolysis by vegetable proteases. Innovative Food Science and Emerging Technologies, 2016. v.37, p.84-90. 
Available from: <https://pubs.acs.org/doi/10.1021/jf103771x>. Accessed: Jun. 30, 2018.

AMBROSI, V. et al. High hydrostatic pressure assisted enzymatic hydrolysis of whey proteins. Innovative Food Science and Emerging Technologies, 2016. v.38, p.294-301. Available from: $\quad<\mathrm{https}: / / \mathrm{www}$. sciencedirect.com/science/article/pii/ S1466856416300868>. Accessed: Oct. 03, 2018.

BELLOQUE, J. et al. . Unfolding and Refolding of b-Lactoglobulin Subjected to High Hydrostatic Pressure at Different $\mathrm{pH}$ Values and Temperatures and Its Influence on Proteolysis. Journal of Agricultural and Food Chemistry, 2007. v.55, n.13, p.52825288. Available from: <https://pubs.acs.org/doi/10.1021/ jf070170w>. Accessed: Jun. 05, 2020.

BOX, G. E. P.; BEHNKEN, D. W. Some New Three Level Desing for Study of quantitative variables Box Behnkee.pdf. Technometrics, 1960 . v.2, n.4, p.455-475. Available from: $<$ https://www.tandfonline.com/doi/abs/10.1080/00401706.1960.1 0489912>. Accessed: May 05, 2020.

BRANDELLI, A.; DAROIT, D. J.; CORRÊA, A. P. F. Whey as a source of peptides with remarkable biological activities. Food Research International, 2015. v.73, p.149-161. Available from: $\quad<\mathrm{https}: / / \mathrm{www}$. sciencedirect.com/science/article/pii/ S0963996915000319>. Accessed: Dec. 12, 2018.

CHEISON, S. C.; KULOZIK, U. Impact of the environmental conditions and substrate pre-treatment on whey protein hydrolysis: A review. Critical Reviews in Food Science and Nutrition, 2017. v.57, n.2, p.418-453. Available from: <https://pubmed.ncbi.nlm. nih.gov/25976220/>. Accessed: Sep. 26, 2019.

CORROCHANO, A. R. et al. Comparison of antioxidant activities of bovine whey proteins before and after simulated gastrointestinal digestion. Journal of Dairy Science, 2019. v.102, n.1.

DUFOUR, E. et al.. Hydrolysis of $\beta$-lactoglobulin by thermolysin and pepsin under high hydrostatic pressure. Biopolymers, 1995. v.35, n.5, p.475-483. Available from: $<$ https://onlinelibrary.wiley. com/doi/abs/10.1002/bip.360350506>. Accessed: Aug. 02, 2019.

FRANCK, M. et al. High hydrostatic pressure-assisted enzymatic hydrolysis improved protein digestion of flaxseed protein isolate and generation of peptides with antioxidant activity. Food Research International, 2018. Available from: $<$ https://pubmed. ncbi.nlm.nih.gov/30599966/>. Accessed: Nov. 11, 2019.

GARCIA-MORA, P. et al. High-pressure improves enzymatic proteolysis and the release of peptides with angiotensin I converting enzyme inhibitory and antioxidant activities from lentil proteins. Food Chemistry, 2015. v.171, p.224-232. Disponível em: $\quad<\mathrm{https}: / / \mathrm{www}$. sciencedirect.com/science/article/abs/pii/ S0308814614013417>. Accessed: Oct. 03, 2018.

GIRGIH, A. T. et al. Enzymatic protein hydrolysates from high pressure-pretreated isolated pea proteins have better antioxidant properties than similar hydrolysates produced from heat pretreatment. Food Chemistry, 2015. v.188, p.510-516. Available from: $\quad<$ https://www.sciencedirect.com/science/article/abs/pii/ S0308814615007463>. Accessed: Apr. 29, 2020.

GOODWIN, T. W.; MORTON, R. A. The spectrophotometric determination of tyrosine and tryptophan in proteins. Biochemical Journal, 1946. v.40, n.5-6, p.628-632. Available from: $\quad<$ http://www.ncbi.nlm.nih.gov/pubmed/16748065>. Accessed: Aug. 29, 2018.

GOYAL, A. et al. High Pressure Processing and Its Impact on Milk Proteins: A Review. Journal of Dairy Science and Technology, 2013. v.2, n.1, p.2319-3409. Available from: <http:// sciencejournals.stmjournals.in/index.php/RRJoDST/article/ view/848>. Acesso em: 30 nov. 2017.

HENDRICKX, M. et al. Efects of high pressure on enzymes related to food quality. Trends in Food Science \& Technology, 1998. v.9, p.197-203. Available from: <https://www.sciencedirect. com/science/article/abs/pii/S0924224498000399>. Accessed: Nov. 29, 2018.

HUPPERTZ, T. et al. High pressure-induced changes in bovine milk proteins : A review. Biochimica et Biophysica Acta, 2006. v. 1764, p. 593-598. Available from: <https://www.sciencedirect. com/science/article/abs/pii/S1570963905004061>. Accessed: Jun. 03, 2018.

HUPPERTZ, T. et al.. High pressure-induced denaturation of a-lactalbumin and b-lactoglobulin in bovine milk and whey: a possible mechanism. Journal of Dairy Research, 2004. v.71, p.489-495. Available from: <https://pubmed.ncbi.nlm.nih. gov/15605716/>. Accessed: May, 25, 2020.

ISKANDAR, M. M. et al. High Hydrostatic Pressure Pretreatment of Whey Protein Isolates Improves Their Digestibility and Antioxidant Capacity. Foods, 2015. v.4, n.2, p.184-207. Available from: <http://www.mdpi.com/2304-8158/4/2/184/>.

LOZANO-OJALVO, D. et al. Pepsin treatment of whey proteins under high pressure produces hypoallergenic hydrolysates. Innovative Food Science and Emerging Technologies, 2017. v. 43 , n. February, p. 154-162. Available from: <http://dx.doi. org/10.1016/j.ifset.2017.07.032>. Accessed: Dec. 12, 2018.

MARCINIAK, A. et al. Enhancing enzymatic hydrolysis of food proteins and production of bioactive peptides using high hydrostatic pressure technology. Trends in Food Science and Technology, 2018. v.80, n. July, p.187-198.

MARSHALL, K. Therapeutic applications of whey protein. Alternative Medicine Review, 2004. v.9, n.2, p.136-156. Available from: $<$ https://pubmed.ncbi.nlm.nih.gov/15253675/>.

MENEZES, E. M. D. S. et al. Efeito da alta pressão hidrostática na atividade de enzimas da polpa de açaí. Ciência e Tecnologia de Alimentos, 2008. v.28, p.14-19. Available from: <https://www.scielo.br/scielo.php?pid=S0101$20612008000500003 \&$ script $=$ sci_abstract $\&$ tlng $=$ pt $>$.

MUNIR, M. et al. Effects of high pressure, microwave and ultrasound processing on proteins and enzyme activity in dairy systems - A review. Innovative Food Science and Emerging Technologies, 2019. v.57, n. February, p.102192. Available from: $<$ https://doi.org/10.1016/j.ifset.2019.102192>.

NONGONIERMA, A. B. et al. Response surface methodology applied to the generation of casein hydrolysates with antioxidant and dipeptidyl peptidase IV inhibitory properties. Journal of the Science of Food and Agriculture, 2016. v.97, n.4, p.1093-1101. Available from: <https://pubmed.ncbi.nlm.nih.gov/27271791/>. Accessed: Nov. 28, 2019. 
OZORIO, L. et al. Whey hydrolysate-based ingredient with dual functionality : From production to consumer 's evaluation. Food Research International, 2019. v.122, n. February, p.123-128. Disponível em: <https:/www.sciencedirect.com/science/article/ abs/pii/S096399691930211X>. Accessed: May, 19, 2020.

PEÑAS, E. et al. Effects of combined high pressure and enzymatic treatments on the hydrolysis and immunoreactivity of dairy whey proteins. International Dairy Journal, 2006. v.16, p.831-839. Disponível em: <https:/www.sciencedirect.com/science/article/ abs/pii/S0958694605001743>. Accessed: Oct. 03, 2018.

PESSATO, T. B. et al. Whey protein isolate hydrolysates obtained with free and immobilized Alcalase: Characterization and detection of residual allergens. Food Research International, 2016. v.83, p.112-120. Disponível em: <https://www. sciencedirect.com/science/article/abs/pii/S0963996916300606>. Accessed: Oct. 27, 2019.

PICCOLOMINI, A. F. et al. High hydrostatic pressure pretreatment of they proteins enhances whey protein hydrolysate inhibition of oxidative stress and IL- 8 secretion in intestinal epithelial cells. Food \& Nutrition Research, 2012. v.56, p.63-69. Available from: <https://pubmed.ncbi.nlm.nih.gov/22723766/>. Accessed: Nov. 10, 2019.

POWER-GRANT, O. et al. In vitro bioactive properties of intact and enzymatically hydrolysed whey protein: Targeting the enteroinsular axis. Food and Function, 2015. v.6, n.3, p.972-980. Available from: <https://pubmed.ncbi.nlm.nih.gov/25666373/>. Accessed: Nov. 10, 2019.

RE, R. et al. Antioxidant activity applying an improved ABTS radical cation decolorization assay. Free Radical Biology \& Medicine, 1999. v.26, n.98, p.1231-1237. Available from: $<$ https://www.sciencedirect.com/science/article/abs/pii/ S0891584998003153>. Accessed: Aug. 29, 2019.

TAVARES, T. G. et al. Manufacture of bioactive peptide-rich concentrates from Whey: Characterization of pilot process.
Journa of Food Engineerin, 2012. v.110, p.547-552. Available from: <https://www.sciencedirect.com/science/article/abs/pii/ S0260877412000295>. Accessed: Oct. 03, 2018.

VILELA, R. M. et al. High hydrostatic pressure enhances whey protein digestibility to generate whey peptides that improve glutathione status in CFTR-deficient lung epithelial cells. Molecular Nutrition and Food Research, 2006. v.50, n.11, p.1013-1029. Available from: <https://pubmed.ncbi.nlm.nih. gov/17054101/>. Accessed: Nov. 10, 2019.

YADAV, J. S. S. et al. Cheese whey: A potential resource to transform into bioprotein, functional/ nutritional proteins and bioactive peptides. Biotechnology Advances, 2015. v.33, n.6, p.756-774. Available from: <https://www.sciencedirect.com/ science/article/abs/pii/S073497501530015X>. Accessed: Oct. 03,2018

YOO, H. et al. High Hydrostatic Pressure-Assisted Enzymatic Treatment Improves Antioxidant and Anti-inflammatory Properties of Phosvitin. Current Pharmaceutical Biotechnology, 2017. v.18, n.2, p.158-167. Available from: <https://pubmed.ncbi.nlm. nih.gov/27981899/>. Accessed: Apr. 26, 2020.

ZHANG, T. et al. Combined effects of high-pressure and enzymatic treatments on the hydrolysis of chickpea protein isolates and antioxidant activity of the hydrolysates. Food Chemistry, 2012. v.135, n.3, p.904-912. Available from: <https://pubmed.ncbi.nlm. nih.gov/22953804/>. Acesso em: 30 out. 2018.

ZHENG, H. et al. Effects of $\mathrm{pH}$, temperature and enzyme-tosubstrate ratio on the antigenicity of whey protein hydrolysates prepared by Alcalase. International Dairy Journal, mar. 2008. v.23, n.1, p.69-82. Available from: <http://www.tandfonline.com/ doi/abs/10.1080/09540105.2011.604770>

ZULUETA, A.; ESTEVE, M. J.; FRÍGOLA, A. ORAC and TEAC assays comparison to measure the antioxidant capacity of food products. Food Chemistry, 2009. v.114, n.1, p.310-316. 